\title{
Development of an Efficient Steel Beam Section for Modular Construction Based on Six-Sigma
}

\author{
Tae-Hyu Ha, ${ }^{1}$ Bong-Ho Cho, ${ }^{2}$ Hongjin Kim, ${ }^{3}$ and Dae-Jin Kim ${ }^{4}$ \\ ${ }^{1}$ POSCO, Seoul, Republic of Korea \\ ${ }^{2}$ Department of Architecture, Ajou University, Suwon, Republic of Korea \\ ${ }^{3}$ Department of Architectural Engineering, Kyungpook National University, Daegu, Republic of Korea \\ ${ }^{4}$ Department of Architectural Engineering, Kyung Hee University, Yongin, Republic of Korea \\ Correspondence should be addressed to Bong-Ho Cho; bhcho@ajou.ac.kr
}

Received 28 September 2016; Accepted 24 October 2016

Academic Editor: Jae-Han Lim

Copyright (c) 2016 Tae-Hyu Ha et al. This is an open access article distributed under the Creative Commons Attribution License, which permits unrestricted use, distribution, and reproduction in any medium, provided the original work is properly cited.

\begin{abstract}
This study presents a systematic approach for the development of an efficient steel beam section for modular construction based on Six-Sigma. Although the Six-Sigma is frequently implemented in manufacturing and other service industries, it is a relatively new concept in the area of building design and construction. As a first step in this approach, market studies and surveys are conducted to obtain the opinions of potential customers. Then the opinions of customers are converted into quality characteristics for the steel beam using the quality function deployment methodology. A steel hollow flanged channel is chosen as the main modular beam shape, and the design concept is derived and developed by applying the Pugh matrix methodology. A pilot test was performed to validate the effectiveness of the developed beam section. The results indicated that the developed channel beam section showed excellent performance and retained high accuracy in fabrication, thus resulting in a significant reduction of steel consumption.
\end{abstract}

\section{Introduction}

Modular construction is an industrialized construction system, with a process that mainly consists of the factory production of preengineered building units, the delivery of the fabricated units to the construction site, and their fast assembly [1]. The structural system of steel frame modular buildings can be largely classified into two types. The first is the beam-column frame system and is suitable for use in school buildings or military barracks, which require relatively large open space [2]. The second is the load-bearing wall system, and dormitories or bachelor officer quarters are good applications of this type as they can be built with a series of transportable unit room modules $[3,4]$.

In general, the modular unit of the beam-column frame system is constructed by connecting structural members such as corner columns, internal columns, floor beams, and ceiling beams by bolting or welding. Figure 1 illustrates an example of standard modules for elementary schools in Korea. The dimensions are $9.8 \mathrm{~m}$ (length), $7.5 \mathrm{~m}$ (column to column span), $3 \mathrm{~m}$ (width), and $3.2 \mathrm{~m}$ (height). Table 1 provides the composition ratio of the main structural members used in this standard module. In the beam-column frame system, the upper beam of the lower level unit is connected with the lower beam of the upper level unit. This connection scheme is called the double beam system. As a result, beam members make up a larger portion of the structural components of the standard module, which is $81 \%$ as shown in Table 1 . The beam members play an important role as they not only contribute greatly to the overall construction cost of modular buildings, but also may affect various factors such as story height and floor vibration. Therefore, the selection of adequate beam members is essential to improving the cost efficiency and performance of modular buildings.

Six-Sigma was first developed by Motorola in the 1980s [5] and became well known in the 1990s when Jack Welch made it central to his business strategy at General Electric. Since the late 1990s, most manufacturing companies in Korea 


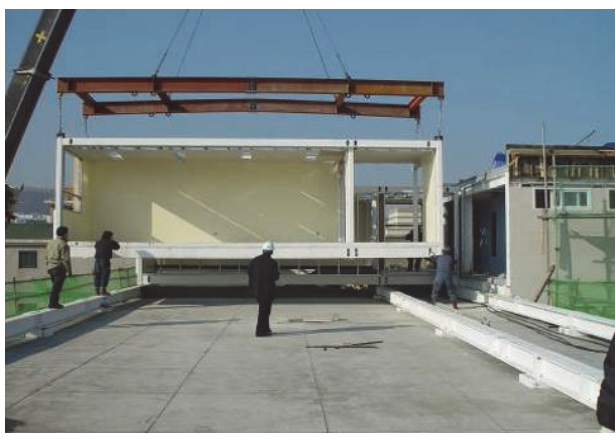

(a) Framed modular unit

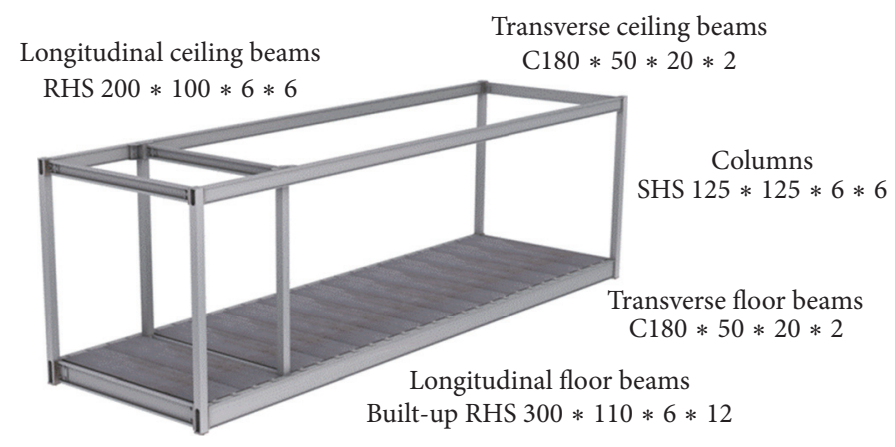

(b) Structural members of the modular unit

FIgURE 1: Standard modular unit and structural members.

TABLE 1: Composition ratio of main structural members used in the standard module.

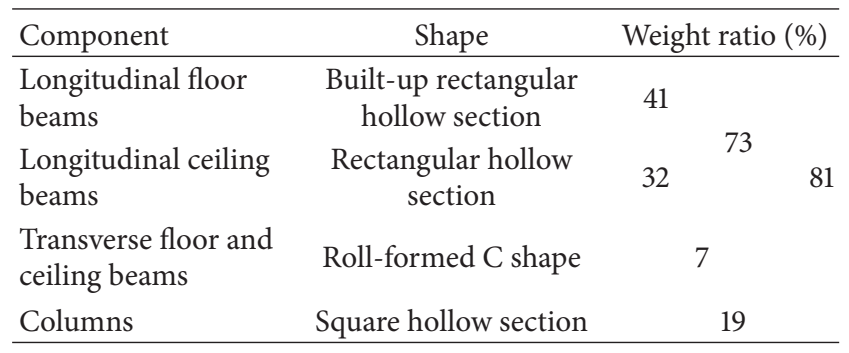

have applied the Six-Sigma for productivity enhancement, process improvement, and new product development. While the Six-Sigma has been applied to construction management and housing design on several occasions such as $[5,6]$, this is one of very few studies where the Six-Sigma concept is employed to develop new steel structural members for modular construction.

In general, Six-Sigma projects follow either the DMAIC or DFSS methodology. The DMAIC focuses on improving an existing business process, while the DFSS aims at creating new products or process designs. Based on this discussion, this study proposes a systematic approach for the development of a steel modular beam section that can be used in the beam-column frame system and validates its effectiveness through a pilot test.

\section{QFD Methodology and Derivation of CTQ}

2.1. QFD Methodology. The philosophy of the Six-Sigma approach emphasizes the reflection of customers' needs in the development of production processes. In order to achieve this, the identification and categorization of potential customers are required, and the importance of each customer group needs to be evaluated. In the Six-Sigma methodology, these customer requirements are referred to as the voice of customers (VOCs), which are obtained through surveys and interviews and utilized as basic data for product development. According to the results of the interviews, module manufacturers require a decrease in manufacturing cost as well as a

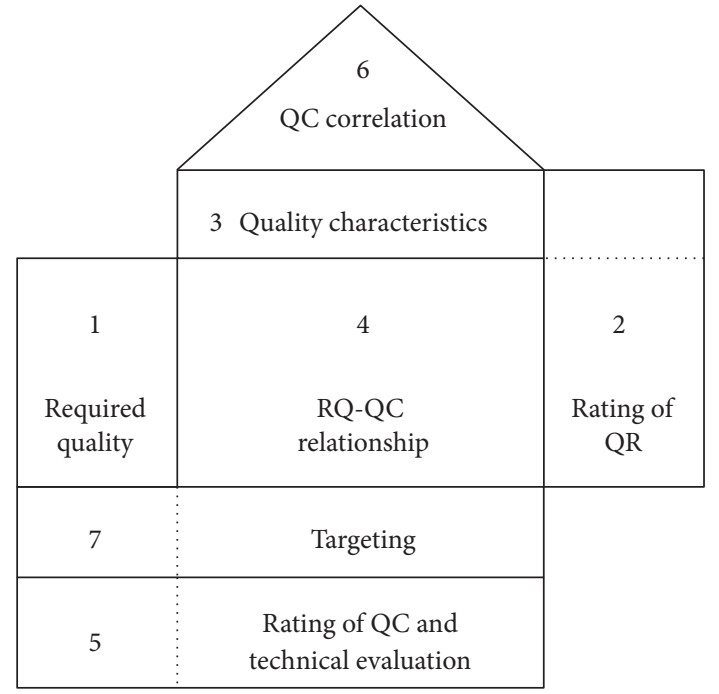

FIGURE 2: HOQ required to conduct QFD.

shortening of order-delivery period, while designers expect various construction-related requirements to be satisfied. The VOC of the building owner is mainly focused on the excellent performance of the manufactured modules.

This study adopts the quality function deployment (QFD) methodology to convert customers' needs into quality characteristics for the products to be developed. The QFD methodology, first proposed by Akao in the 1960s [7], is a tool that can provide a quantitative evaluation on the relation between customer requirements and product characteristics using a correlation matrix $[8,9]$. Figure 2 illustrates the house of quality (HOQ), which is required to conduct QFD.

In general, the QFD methodology follows a number of procedures: (1) determination of required quality; (2) importance rating for customers' needs; (3) identification of quality characteristics; (4) correlation analysis between the required quality and quality characteristics; (5) technical evaluation; (6) interrelation analysis of the quality characteristics if required; (7) target specification setup for the quality characteristics. In this study, the required quality is 
TABLE 2: Priority rating for the customer requirements.

\begin{tabular}{|c|c|c|c|c|c|c|c|c|}
\hline $\begin{array}{l}\text { Customers' required } \\
\text { quality }\end{array}$ & $\begin{array}{l}\text { (1) Importance } \\
\text { rating }\end{array}$ & $\begin{array}{l}\text { (2) Satisfaction } \\
\text { rating }\end{array}$ & $\begin{array}{c}\text { (3) Possible } \\
\text { quality levels }\end{array}$ & $\begin{array}{l}\text { (4) Level-up } \\
\text { ratio }\end{array}$ & $\begin{array}{l}\text { (5) Sales } \\
\text { Point }\end{array}$ & $\begin{array}{l}\text { (6) Absolute } \\
\text { priority }\end{array}$ & $\begin{array}{c}\text { Priority } \\
\text { Ratios }\end{array}$ & Ratings \\
\hline Small steel quantity & 4.6 & 2.8 & 4 & 1.4 & O & 7.7 & $10 \%$ & 2 \\
\hline Low manufacturing cost & 4.6 & 2.6 & 5 & 1.9 & (0) & 13.1 & $17 \%$ & 1 \\
\hline Easy structural design & 3.6 & 3.4 & 4 & 1.2 & & 4.3 & $5 \%$ & 7 \\
\hline Easy architectural design & 3.6 & 3.4 & 4 & 1.2 & & 4.3 & $5 \%$ & 7 \\
\hline Easy connection & 3.6 & 3.4 & 4 & 1.2 & & 4.3 & $5 \%$ & 7 \\
\hline $\begin{array}{l}\text { Transportation with } \\
\text { low-bed trailer }\end{array}$ & 3.6 & 3.2 & 4 & 1.3 & & 4.7 & $6 \%$ & 5 \\
\hline $\begin{array}{l}\text { Transportation with } \\
\text { cargo truck }\end{array}$ & 3 & 3 & 3 & 1 & & 3 & $4 \%$ & 15 \\
\hline $\begin{array}{l}\text { Easy installation of } \\
\text { plumbing equipment }\end{array}$ & 3.4 & 3.2 & 4 & 1.3 & & 4.4 & $6 \%$ & 6 \\
\hline $\begin{array}{l}\text { A short time for stocking } \\
\text { after order }\end{array}$ & 3.6 & 2.8 & 4 & 1.4 & O & 6 & $8 \%$ & 4 \\
\hline $\begin{array}{l}\text { The stock is secured in } \\
\text { advance }\end{array}$ & 3 & 2.6 & 3 & 1.2 & 0 & 4.3 & $5 \%$ & 7 \\
\hline $\begin{array}{l}\text { Small manufacturing } \\
\text { deformation }\end{array}$ & 3.8 & 3 & 4 & 1.3 & (0) & 7.4 & $9 \%$ & 3 \\
\hline Less surface defects & 3.6 & 2.8 & 3 & 1.1 & & 4 & $5 \%$ & 12 \\
\hline $\begin{array}{l}\text { Easy application of } \\
\text { high-strength steel }\end{array}$ & 3 & 2.8 & 3 & 1.1 & & 3.3 & $4 \%$ & 14 \\
\hline Structural safety & 3.6 & 3.6 & 4 & 1.1 & & 4 & $5 \%$ & 12 \\
\hline Less floor vibration & 4.2 & 4 & 4 & 1 & & 4.2 & $5 \%$ & 11 \\
\hline
\end{tabular}

(1) Importance rating: values obtained from customer survey (1 5).

(2) Satisfaction rating: values obtained from customer survey (1 5).

(3) Quality levels that may be obtained from the viewpoint of developers (1 5).

(4) Level up ratio: (3)/(2).

(5) Sales point from the viewpoint of developers (๑: 1.5, ○: 1.2).

(6) Absolute priority: $(1) *(4) *(5)$.

determined from the VOCs obtained from the first round of interviews, and then the quality characteristics are prioritized based on the evaluations of customers and experts. Finally, the target values and importance ratings for the quality characteristics are assigned.

In this study, QFD methodology is used for the development of a new steel modular beam section. The results of priority ratings for the VOCs, where the requirements of both customers and product developers are considered, are provided in Table 2. The item labeled "customers' required quality" in Table 2 is a reorganization of the VOCs of each customer group for QDF analysis, and its priority ratings are determined based on the results of the customer surveys. From the results of the table, items with high priority are found to have "low manufacturing cost," "small steel quantity," "small manufacturing deformation," and "short time for stocking after order." In the determination of the priority rating in Table 2, the importance of customers' requirements and satisfaction with existing products are determined from the surveys. The "planning quality" and "sales point" in Table 2 are the indicators for the attainable quality and sales quantity from the perspective of developers, respectively.
2.2. Derivation of CTQ. From a correlation analysis between the required qualities and quality characteristics, parameters that are critical to quality (CTQ) from the customers' perspective can be derived. The quality characteristics are given different weight values (๑: 5 points, $\bigcirc: 3$ points, and $\triangle: 1$ point) depending on the relationship with the corresponding customer requirements. The overall importance can be calculated by summing up the multiplications of the weighted value and absolute importance in Table 3. The quality characteristics with high importance score can be selected as the potential CTQs.

This process of deriving CTQs is important in the SixSigma methodology, which reflects the customers' needs as much as possible. The VOC does not contain any direct statements on the quality characteristic, but it can be converted into designable quality characteristics through QFD analysis. Table 3 lists the importance ratings derived from the correlation analysis on the required quality and quality characteristics.

From the QFD analysis, the quality characteristics with high importance are found to be "weld length per unit length," "moment of inertia per sectional area of beam," and "weight of floor beams per unit area of plan." These items 


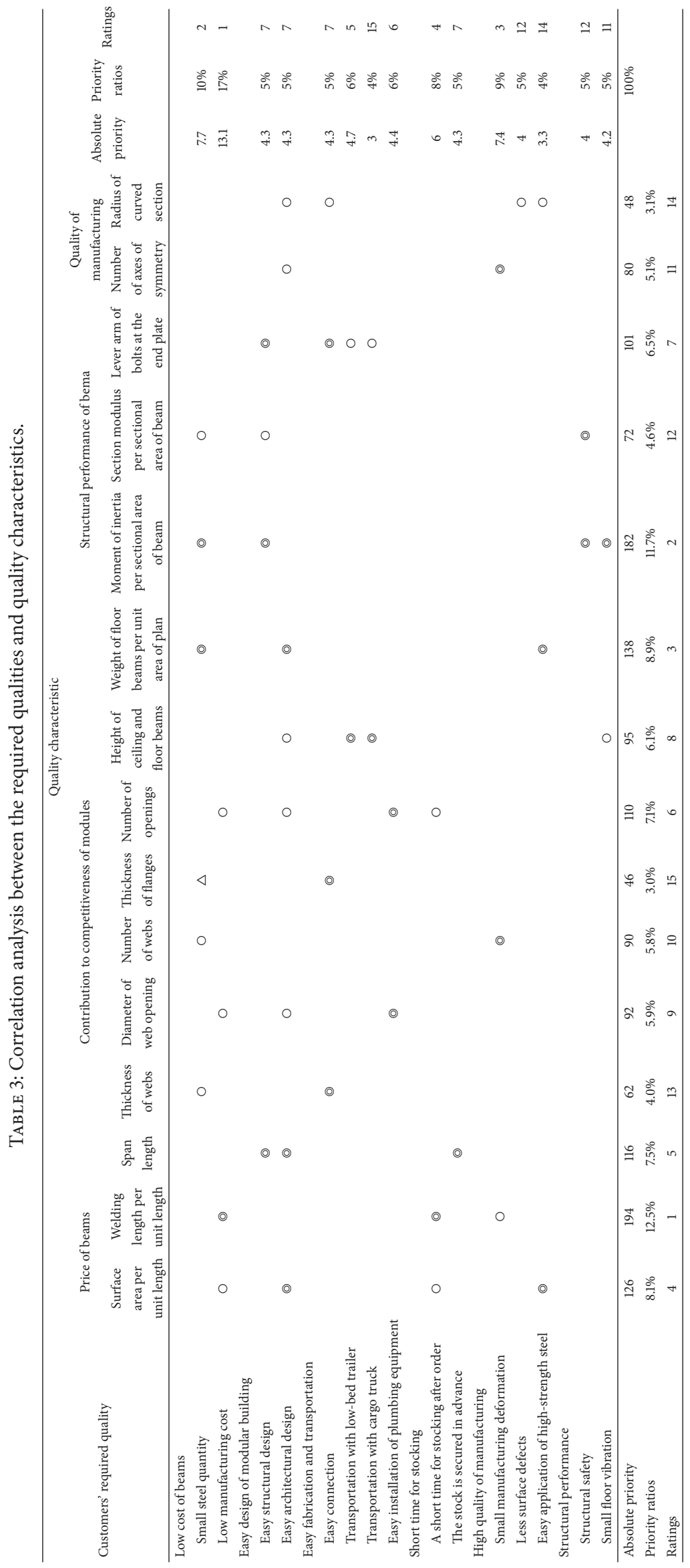


TABLE 4: CTQ definitions and target levels.

\begin{tabular}{|c|c|c|c|c|c|}
\hline \multirow{2}{*}{ CTQ } & \multirow{2}{*}{ Definition } & \multirow{2}{*}{ Measuring method } & \multicolumn{2}{|c|}{ Current level } & \multirow{2}{*}{ Target level } \\
\hline & & & Built-up RHS & Channel & \\
\hline $\begin{array}{l}\text { Welding length per unit } \\
\text { length }\end{array}$ & $\begin{array}{l}\text { Welding length per } 1 \mathrm{~m} \\
\text { beam length }\end{array}$ & Measuring welding length & 4 & 0 & Less than 2 \\
\hline $\begin{array}{l}\text { Moment of inertia per } \\
\text { sectional area of beam }\end{array}$ & $\begin{array}{l}\text { Moment of inertia divided } \\
\text { by sectional area of beam }\end{array}$ & $\begin{array}{l}\text { Calculation of moment of } \\
\text { inertia and sectional area of } \\
\text { beams }\end{array}$ & $\begin{array}{c}127 \mathrm{~cm}^{2} \\
(7.5 \mathrm{~m} \mathrm{span})\end{array}$ & $\begin{array}{c}132 \mathrm{~cm}^{2} \\
(7.5 \mathrm{~m} \mathrm{span})\end{array}$ & $\begin{array}{l}\text { Larger than } 150 \mathrm{~cm}^{2} \\
(7.5 \mathrm{~m} \mathrm{span})\end{array}$ \\
\hline $\begin{array}{l}\text { Weight of floor beams per } \\
\text { unit area of plan }\end{array}$ & $\begin{array}{l}\text { Total weight of beams used } \\
\text { for modules divided by } \\
\text { plan area of module }\end{array}$ & $\begin{array}{l}\text { Calculation of weight of } \\
\text { beams after redesign of } \\
\text { modules }\end{array}$ & $\begin{array}{l}0.30 \mathrm{kN} / \mathrm{m}^{2} \\
(7.5 \mathrm{~m} \mathrm{span})\end{array}$ & $\begin{array}{l}0.25 \mathrm{kN} / \mathrm{m}^{2} \\
(7.5 \mathrm{~m} \mathrm{span})\end{array}$ & $\begin{array}{c}\text { Less than } 0.28 \mathrm{kN} / \mathrm{m}^{2} \\
(7.5 \mathrm{~m} \mathrm{span})\end{array}$ \\
\hline
\end{tabular}

TABLE 5: Classification of key functions for the steel modular beam section.

\begin{tabular}{|c|c|c|c|c|}
\hline Main process & Manufacturing beams & Assembly of modules & Transportation and installing & $\begin{array}{l}\text { Ensuring structural } \\
\text { performance }\end{array}$ \\
\hline Must be functions & - & $\begin{array}{c}\text { Welding end-plate } \\
\text { Connecting beam and } \\
\text { column } \\
\text { Connecting beam and slab } \\
\text { Connecting beam and } \\
\text { ceiling track } \\
\text { Connecting beam and wall } \\
\text { track }\end{array}$ & Transportation of modules & $\begin{array}{l}\text { Flexural strength of beam } \\
\text { Shear strength of beam } \\
\text { Minimize deflection of beam } \\
\text { Minimize floor vibration } \\
\text { Earthquake and wind } \\
\text { resistance } \\
\text { Fire resistance }\end{array}$ \\
\hline Delighter functions & - & - & $\begin{array}{c}\text { Plumbing equipment } \\
\text { penetration }\end{array}$ & - \\
\hline $\begin{array}{l}\text { Primary satisfier } \\
\text { functions }\end{array}$ & $\begin{array}{c}\text { Minimize a space for } \\
\text { stock }\end{array}$ & - & - & - \\
\hline
\end{tabular}

are selected as CTQs in the following step and expressed quantitatively. Among the 15 quality characteristics, the top 3 items are selected as CTQs and defined as shown in Table 4, which shows their definitions, measurement methods, current, and target levels. The target levels are determined using the existing built-up RHS (rectangular hollow sections) and channels as references.

\section{Product Design Using Pugh Matrix Methodology}

3.1. Function Analysis and Pugh Matrix. The core functions of the steel modular beam section are determined and its optimal design is developed utilizing the CTQs derived in the previous phase. Table 5 describes the main processes required for the manufacturing of the steel modular beam section and classifies the functions required in each process into one of three functions, namely, the basic function (necessary), attractive function (delighter), and discriminative function (primary satisfier). The basic functions must be satisfied, while the attractive and differentiated functions can be optionally considered in the design process.

Key functions can be determined from a correlation analysis between the quality characteristics and associated functions by applying the same method used to create CTQs in Table 3. Table 6 shows the relationship between the quality characteristics and the key functions. From this relationship, "minimize deflection and vibration of beam," "flexural strength of beam," "earthquake and wind resistance," and "piping equipment penetration" are selected as key functions.

After derivation of the key functions, an optimal design concept satisfying the derived key functions needs to be developed. In order to achieve this, various methods can be used such as the benchmarking of advanced technologies, brainstorming by experts, TRIZ, and mind mapping. In this study, various solutions that can satisfy the key functions are created, and several possible design options are obtained by combining these solutions. Finally, the Pugh matrix is employed to select the optimal design among the designs obtained.

Table 7 lists the available solutions for each of the key functions of the steel modular beam section. The table indicates that there are two solutions for "piping equipment penetration" and "connecting beam and slab," four solutions for structural functions, specifically "flexural strength of beam," "minimize deflection and vibration of beam," and "earthquake and wind resistance," and one solution for all of the remaining functions. These solutions can be combined to produce an optimal design concept. By combining the solutions listed in Table 7, seven design concepts are derived. They satisfy various functions required for the floor and ceiling 


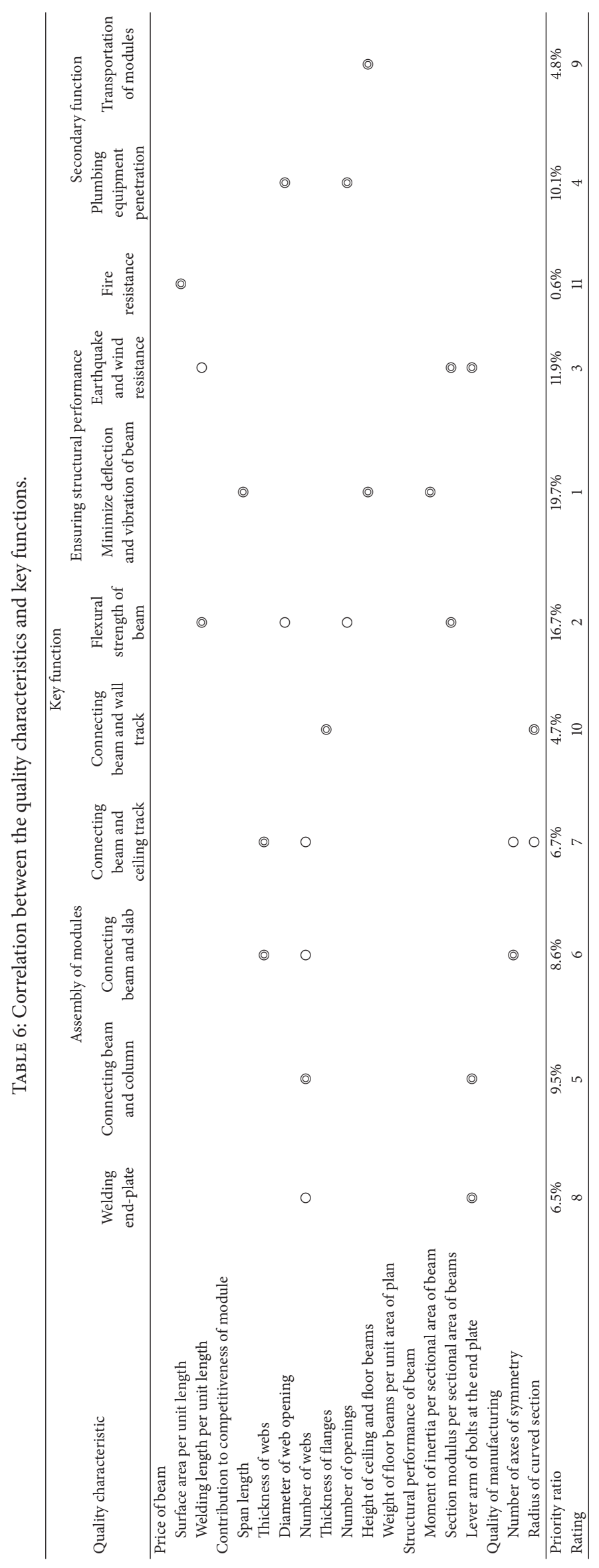


TABLE 7: Available solutions for each of the key functions.

\begin{tabular}{|c|c|c|c|c|}
\hline Key functions & \multicolumn{4}{|c|}{ Solutions } \\
\hline Piping equipment penetration & \multicolumn{2}{|c|}{$\begin{array}{l}\text { Install reinforcing device at penetration } \\
\text { Solution A }\end{array}$} & \multicolumn{2}{|c|}{$\begin{array}{l}\text { Penetrate without reinforcing } \\
\text { Solution B }\end{array}$} \\
\hline Transportation of modules & \multicolumn{4}{|c|}{ Limiting module height less than $3.3 \mathrm{~m}$} \\
\hline Welding end-plate & \multicolumn{4}{|c|}{ Limiting flange width less than $120 \mathrm{~mm}$} \\
\hline Connecting beam and column & \multicolumn{4}{|c|}{ Ensuring bolting space at end-plate } \\
\hline Connecting beam and slab & \multicolumn{2}{|c|}{$\begin{array}{l}\text { Integrate beam and slab support } \\
\text { Solution a }\end{array}$} & \multicolumn{2}{|c|}{$\begin{array}{c}\text { Separate beam and slab support } \\
\text { Solution } b\end{array}$} \\
\hline $\begin{array}{l}\text { Connecting beam and ceiling } \\
\text { track }\end{array}$ & \multicolumn{4}{|c|}{ Connect track to web of beam with screw } \\
\hline $\begin{array}{l}\text { Connecting beam and wall } \\
\text { track }\end{array}$ & \multicolumn{4}{|c|}{ Ensuring flange width of $60 \mathrm{~mm}$} \\
\hline $\begin{array}{l}\text { Flexural strength of beam } \\
\text { Minimize deflection and } \\
\text { vibration of beam }\end{array}$ & $\begin{array}{l}\text { Use hollow flange (flange } \\
\text { thickness = web } \\
\text { thickness) }\end{array}$ & $\begin{array}{l}\text { Use hollow flange (flange } \\
\text { thickness > web } \\
\text { thickness) }\end{array}$ & $\begin{array}{l}\text { Use open flange (flange } \\
\text { thickness = web } \\
\text { thickness) }\end{array}$ & $\begin{array}{l}\text { Use open flange (flange } \\
\text { thickness }>\text { web } \\
\text { thickness) }\end{array}$ \\
\hline $\begin{array}{l}\text { Earthquake and wind } \\
\text { resistance }\end{array}$ & Solution I & Solution II & Solution III & Solution IV \\
\hline
\end{tabular}

TABLE 8: Design concepts obtained by combinations of the available solutions.

\begin{tabular}{|c|c|c|c|c|c|c|c|}
\hline $\begin{array}{l}\text { Combination of } \\
\text { solutions }\end{array}$ & $\begin{array}{l}\text { Solutions } \\
\mathrm{A}+\mathrm{a}+\mathrm{I}\end{array}$ & $\begin{array}{l}\text { Solutions } \\
\mathrm{A}+\mathrm{b}+\mathrm{I}\end{array}$ & $\begin{array}{l}\text { Solutions } \\
\mathrm{A}+\mathrm{a}+\mathrm{II}\end{array}$ & $\begin{array}{l}\text { Solutions } \\
\mathrm{A}+\mathrm{b}+\mathrm{II}\end{array}$ & $\begin{array}{l}\text { Solutions } \\
\mathrm{B}+\mathrm{a}+\mathrm{III}\end{array}$ & $\begin{array}{l}\text { Solutions } \\
\text { B + b + III }\end{array}$ & $\begin{array}{l}\text { Solutions } \\
\mathrm{B}+\mathrm{b}+\mathrm{IV}\end{array}$ \\
\hline \multicolumn{8}{|l|}{ Design concepts } \\
\hline $\begin{array}{l}\text { Manufacturing } \\
\text { cost }\end{array}$ & Very high & High & Very high & Very high & Middle & Middle & Very high \\
\hline Steel quantity & Very low & Low & Very low & Very low & Low & High & Low \\
\hline $\begin{array}{l}\text { Compatibility } \\
\text { between floor and } \\
\text { ceiling beam }\end{array}$ & $\begin{array}{c}\text { Not } \\
\text { compatible }\end{array}$ & Compatible & $\begin{array}{c}\text { Not } \\
\text { compatible }\end{array}$ & Compatible & $\begin{array}{c}\text { Not } \\
\text { compatible }\end{array}$ & Compatible & Compatible \\
\hline
\end{tabular}

beams of the modular beam-column frame system and show different characteristics with regard to manufacturing cost, steel consumption, and availability for both of ceiling and floor beams. Their characteristics are summarized in Table 8 .

In order to select the optimal design among the candidates listed in Table 8, a Pugh matrix is created in Table 9. In this methodology, a relative evaluation is performed on each candidate by comparing it with the reference design for each of the key criteria. The built-up RHS is chosen as the reference design for this comparison. Thus, if a candidate shows better performance than the reference design, it is denoted as + . If the candidate is worse than or is equal to the reference design, it is denoted as - or S, respectively. The candidate with the greatest difference between the sum of pluses and that of minuses is chosen as the optimal design. The results in Table 9 indicate that design concept 2 is the optimal design. Thus, it is selected as the prototype for the steel modular beam section.
The prototype has hollow flanges in both the upper and lower parts of the section as shown in Table 9. It can be manufactured by a roll forming method, in which thin steel sheets are passed through several rolls and are consecutively bent at room temperature. The cross-sectional shape is illustrated in Figure 3. The steel beam member with the cross-sectional shape shown in Figure 3 is hereafter referred to as the modular construction optimized (MCO) beam for convenience.

3.2. Detailed Design of MCO Beams. In this section, a detailed design of the MCO beam is discussed considering the manufacturing process. With the detailed design components, the cross-section has a variable portion as well as an invariable portion as shown in Figure 4. Although MCO beams manufactured through the roll forming process require smaller manufacturing costs than general built-up beams, a variety in depth is also necessary for their applications to modular 
TABLE 9: Selection of the optimal design using the Pugh matrix methodology.

\begin{tabular}{|c|c|c|c|c|c|c|c|c|c|}
\hline $\begin{array}{l}\text { Better } \\
\text { Same S } \\
\text { Worse }\end{array}$ & & Reference & Concept 1 & Concept 2 & Concept 3 & Concept 4 & Concept 5 & Concept 6 & Concept 7 \\
\hline Key criteria & Weight & & & & & & & & \\
\hline Manufacturing cost & 5 & S & + & + & S & S & + & + & - \\
\hline Fire proofing cost & 4 & S & - & - & - & - & - & - & - \\
\hline Steel quantity & 4 & $S$ & + & + & + & + & - & - & + \\
\hline Easy fabrication & 3 & $S$ & + & + & + & + & + & + & + \\
\hline New investment & 5 & S & - & - & - & - & + & + & - \\
\hline Compatibility & 4 & S & - & + & - & + & - & + & - \\
\hline Creativity & 3 & S & + & + & + & + & S & $S$ & $S$ \\
\hline Sum of + & & 0 & 4 & 5 & 3 & 4 & 3 & 4 & 2 \\
\hline Sum of - & & 0 & 3 & 2 & 3 & 2 & 3 & 2 & 4 \\
\hline Sum of S & & 7 & 0 & 0 & 1 & 1 & 1 & 1 & 1 \\
\hline Weighted sum of + & & 0 & 15 & 19 & 10 & 14 & 13 & 17 & 7 \\
\hline Weighted sum of - & & 0 & 13 & 9 & 13 & 9 & 12 & 8 & 18 \\
\hline
\end{tabular}

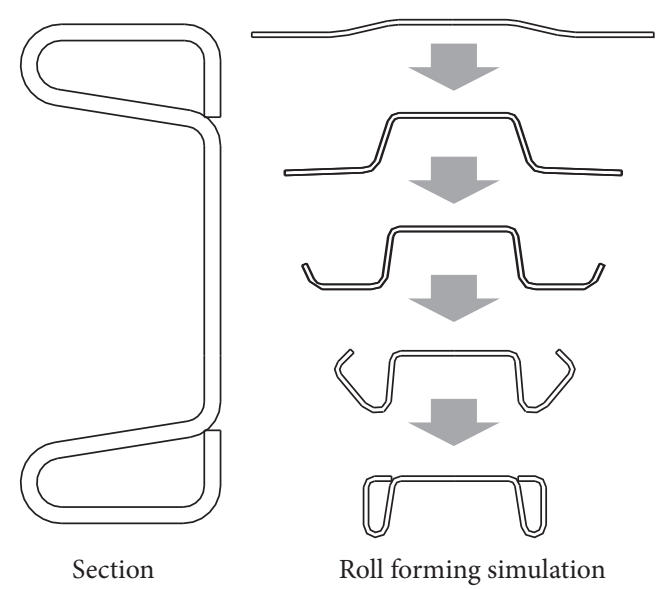

FIgURE 3: Cross-sectional shape of the MCO beam and its roll forming simulation.

buildings with diverse spans. Therefore, the upper and lower hollow flange parts are designed as the invariable portion and produced using a single roll. In contrast, the thickness and width of the web section are variable. The design requirements for each design factor of the MCO beam are listed in Table 10. SPA-H steel is used for manufacturing the MCO beams since it has high durability as well as a high tensile strength of $490 \mathrm{MPa}$.

The design procedures for the MCO beam with invariable cross-section (hollow flange) can be summarized as follows.

Step 1 (setting up the range of the flange width as shown in Figure 5). (i) If the minimum width of the column is $125 \mathrm{~mm}$, the flange width is in the range of $100 \sim 120 \mathrm{~mm}$.

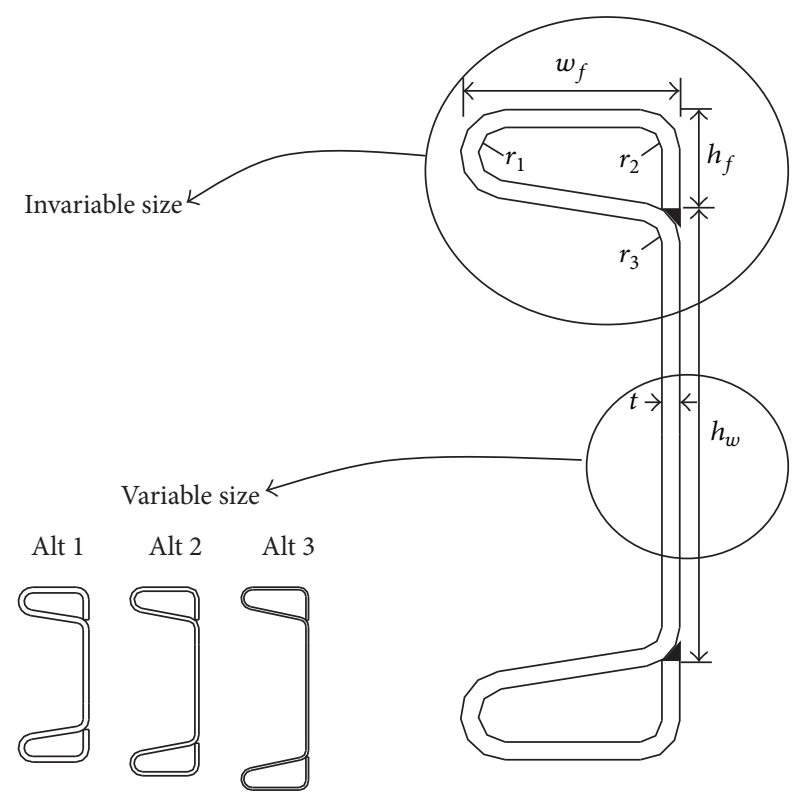

Figure 4: Cross-sectional design of the MCO beam.

(ii) The minimum width of the horizontal flat flange portion must be at least $50 \mathrm{~mm}$.

Step 2 (determination of $r_{1}$ and $r_{2}$ shown in Figure 6). These parameters are constant regardless of the steel plate thickness if the same roll forming process is used.

(i) Bending capacity of SPA-H steel: if the bending angle is 180 degrees, the inner radius must be at least 1.5 times the flange thickness. 
TABLE 10: Design requirements for each design factor of the MCO beam.

\begin{tabular}{ll}
\hline Design factor & Design requirement \\
\hline Invariable section & (i) Limit the flange width to less \\
than the column width (column \\
width: $125 \mathrm{~mm}$ or $150 \mathrm{~mm}$ ) \\
(ii) Require the minimum flat flange \\
width $(50 \mathrm{~mm}$ ) to be connected to \\
the wall stud \\
Flange width
\end{tabular}

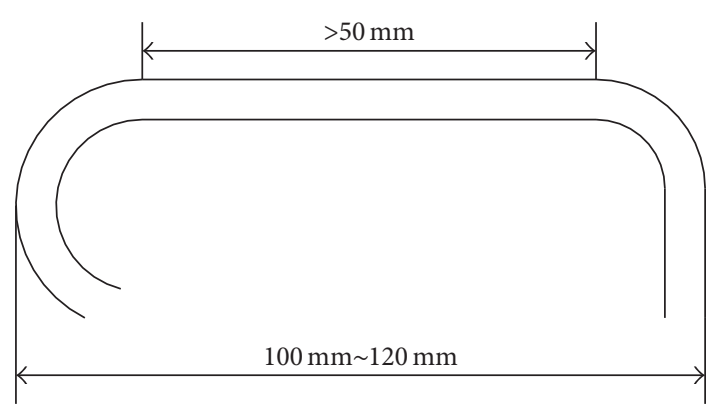

FIGURE 5: Range of the flange width.

(ii) The maximum steel plate thickness is limited to $10 \mathrm{~mm}$.

(iii) If the bending angle of $r_{1}$ is in the range of 90 to 180 degrees, $r_{1}=15 \mathrm{~mm}$.

(iv) If the bending angle of $r_{2}$ is 90 degrees, $r_{2}=12 \mathrm{~mm}$.

Step 3 (determination of the flange width). (i) If the steel plate thickness is $10 \mathrm{~mm}$ and $r_{1}$ and $r_{2}$ are 15 and $12 \mathrm{~mm}$, respectively, the flat flange width is in the range of 53 to $73 \mathrm{~mm}$, thus satisfying the condition in Step 1.

(ii) The flange width is determined as $120 \mathrm{~mm}$, which is the maximum value allowed by the condition in Step 1, considering its easy attachment onto ceilings and floor tracks.

Step 4 (determination of $r_{3}$ ). This value is constant if the same roll forming process is used regardless of the flange thickness.

(i) If bending angle of $r_{3}$ is less than 90 degrees, $r_{3}=$ $12 \mathrm{~mm}$, which is the same as $r_{2}$.

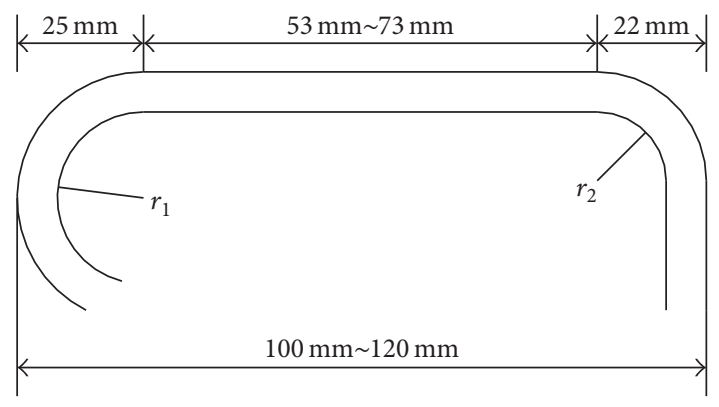

FIGURE 6: Determination of $r_{1}$ and $r_{2}$.

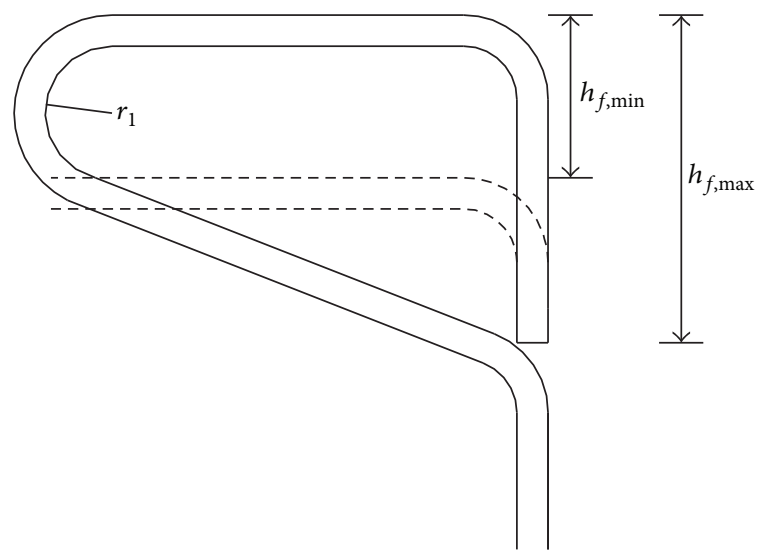

FIGURE 7: Determination of the flange height.

Step 5 (setting up the range of the flange height shown in Figure 7). (i) If it is assumed that the upper and lower flanges are parallel to each other and the flange thickness is $10 \mathrm{~mm}$, $h_{f, \min 1}=10+15+15+10=50 \mathrm{~mm}$.

(ii) The flange height can be calculated by considering the maximum beam height of $400 \mathrm{~mm}$ and minimum steel plate thickness of $4.5 \mathrm{~mm}$ and applying the maximum widththickness ratio of 61 to prevent elastic local buckling as $h_{f, \min 2}$ $=(400-61 \times 4.5) / 2=63 \mathrm{~mm}$.

Step 6 (final selection of invariable dimensions of the upper hollow flange). (i) Front welding is performed on the steel plate connection as shown in Figure 8.

The following design conditions for the variable portion of the MCS beam cross-section are assumed for three module spans of $6,7.5$, and $8.1 \mathrm{~m}$ : floor beam load in the range of $2 \sim 5 \mathrm{kN} / \mathrm{m}^{2}$, floor beam live load in the range of $2 \sim 5 \mathrm{kN} / \mathrm{m}^{2}$, ceiling beam load in the range of $0.3 \sim 0.5 \mathrm{kN} / \mathrm{m}^{2}$, and ceiling beam live load in the range of $0.5 \sim 1 \mathrm{kN} / \mathrm{m}^{2}$. Various crosssectional shapes for the MCO beam are designed by changing the steel plate thickness and web height as design variables, while satisfying the requirements on the dimensions of the cross-section discussed above. As shown in Table 11, 6 steel plate thickness values and 7 web heights are used as design values. The effective moment of inertia for the cross-sections 


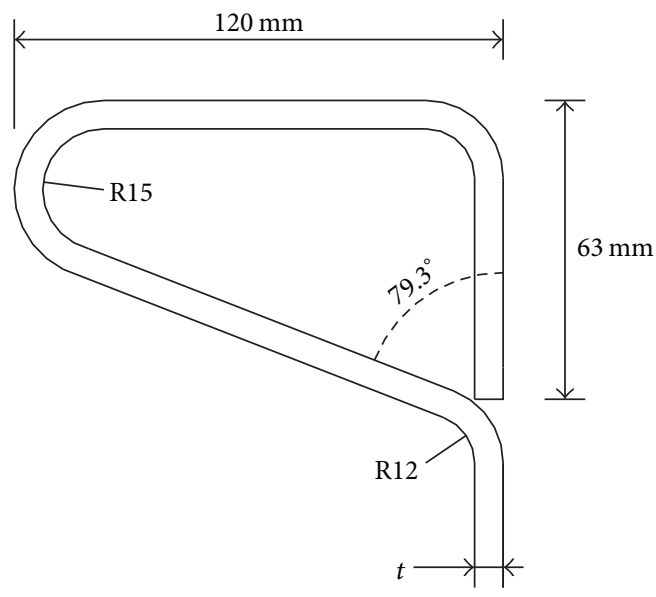

FIGURE 8: Invariable dimensions of the upper hollow flange of the MCO beam.

TABLE 11: Design requirements and values on the variable sectional portion of the MCO beam.

\begin{tabular}{lcl}
\hline Design factors & $\begin{array}{c}\text { Design } \\
\text { requirements }\end{array}$ & Design values \\
\hline Thickness of & $\begin{array}{c}\text { Use standard } \\
\text { steel plate }\end{array}$ & $\begin{array}{l}\text { (i) } 4.5 \mathrm{~mm}, 6 \mathrm{~mm}, 7 \mathrm{~mm}, \\
8 \mathrm{~mm}, 9 \mathrm{~mm}, 10 \mathrm{~mm}\end{array}$ \\
& $\begin{array}{l}\text { (i) Floor beam: } 270 \mathrm{~mm}, \\
300 \mathrm{~mm}, 330 \mathrm{~mm}, 360 \mathrm{~mm},\end{array}$ \\
Depth of beam & $\begin{array}{c}\text { Apply modular } \\
\text { coordinate }\end{array}$ & $\begin{array}{l}390 \mathrm{~mm} \\
\text { (ii) Ceiling beam: } 200 \mathrm{~mm}, \\
\end{array}$ \\
& & $240 \mathrm{~mm}$ \\
\hline
\end{tabular}

in the table ranges from 1,530 to $18,218 \mathrm{~cm}^{4}$. A total of 42 of the designed MCO beam cross-sectional shapes are given in Figure 9 .

\section{Design Verification and Pilot Test}

As the final stage of the DFSS methodology, MCO beam rolls are produced using the roll forming facilities of a local company in Korea, and their formability and welding workability are assessed. Figure 10 shows the procedure for a pilot production of the MCO beam sections developed. A long strip in coiled steel is passed through sets of rolls until a shape with upper and lower hollow flanges is obtained. Then the production of the MCO beam section is completed by performing welding on the roll formed shape. Figure 11 shows an example of the assembled modular unit with the produced MCO beams.

The results of CTQ and productivity assessments on the final products are summarized in Table 12. The deformation level of the MCO beam that occurs during its production is less than $5 \mathrm{~mm}$ per $10 \mathrm{~m}$. While some deformation may take place during secondary machining such as welding of brackets and end plates, additional correction can be performed in the process of module assembly, resulting in an error less than $3 \mathrm{~mm}$ per unit module. To confirm that the produced beams have a sufficient moment of inertia per unit cross-sectional area, a total of 150 cases are tested for various floor spans and loading conditions. The results of the test show that the average floor span is $183.38 \mathrm{~cm}^{2}$ and the standard deviation is $16 \mathrm{~cm}^{2}$. Thus, the average is well above the design target, which is $160 \mathrm{~cm}^{2}$. For three spans of $6,7.5$, and $8.1 \mathrm{~m}$, floor beams with optimal cross-sections are selected, and then the weight of the floor beams per unit area is evaluated for each case. It can be seen from the results of the table that target values are met for all of the three cases.

\section{Concluding Remarks}

In this study, a systematic approach was presented for the development of an efficient steel beam section for modular construction based on Six-Sigma. As the first step of this approach, market studies and surveys are conducted to obtain the opinions of potential customers. Then the opinions of the customers were converted into the quality characteristics for the channel-shaped steel beam using the quality function deployment methodology. A steel hollow flanged channel was chosen as the main modular beam shape, and the design concept was derived and developed by applying the Pugh matrix methodology. A pilot test was performed to validate the effectiveness of the developed beam section. The main conclusions of this study are as follows:

(1) To reflect customers' needs in the development of production processes, the QFD methodology was applied, and "welding length per unit length," "moment of inertia per sectional area of beam," and "weight of floor beams per unit area of plan" were selected as CTQs. Quantitative target values for these items were also set up.

(2) Seven design concepts were developed from an analysis on the key functions of the steel modular beam to satisfy the derived CTQs. The Pugh matrix methodology was applied to derive the optimal design of the steel modular beam, which has hollow flanges at the top and bottom.

(3) In the final product design, the cross-section of the MCO beam has the upper and lower hollow flange parts as the invariable portion and the web section as the variable portion. The results of the pilot production of the MCO beam indicate that the weight of the floor beams per unit area can be reduced to an average of $0.25 \mathrm{kN} / \mathrm{m}^{2}$ for the standard $7.5 \mathrm{~m}$ span, which is $18 \%$ less than the corresponding value for the built-up RHS beam. All the modules assembled with the MCO beam products show an error less than $3 \mathrm{~mm}$ per unit module, thus satisfying the target value.

(4) Based on the DFSS methodology of Six-Sigma, this study proposed a methodology which can effectively reflect customers' needs, such as the reduction of manufacturing cost, less material usage, and reduced structural deformation of modular units, in the product design. It is expected that the proposed method 


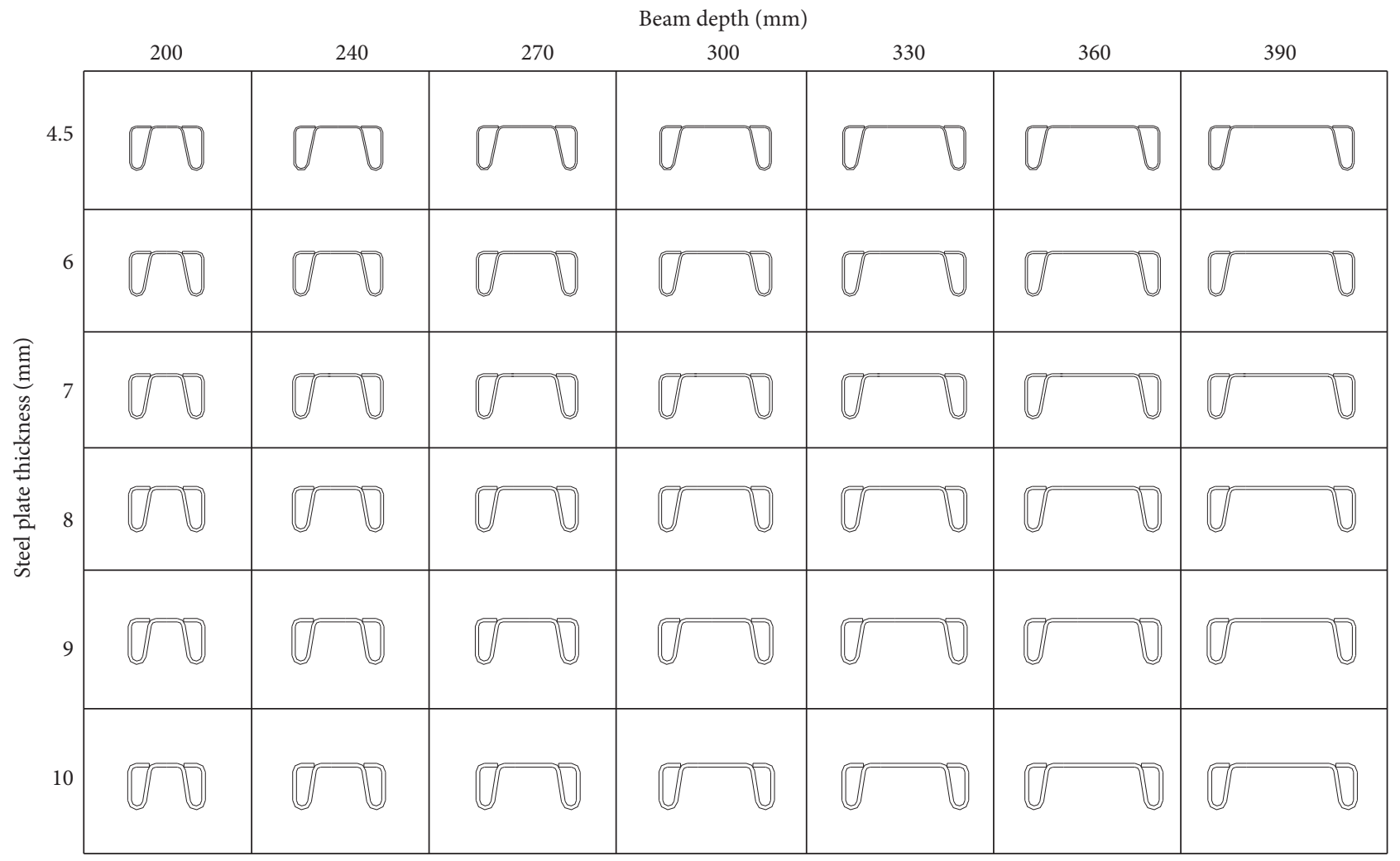

FIgURE 9: Developed cross-sectional shapes for the MCO beam.

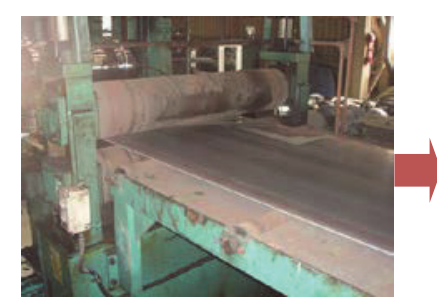

Uncoil

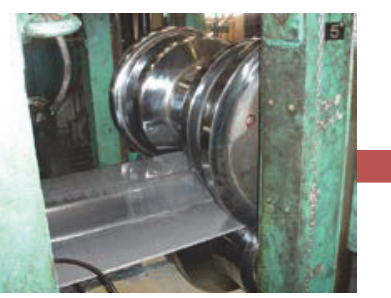

Roll forming manufacture

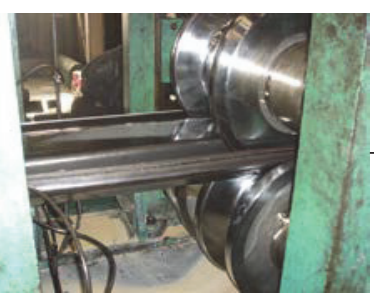

Roll forming manufacture

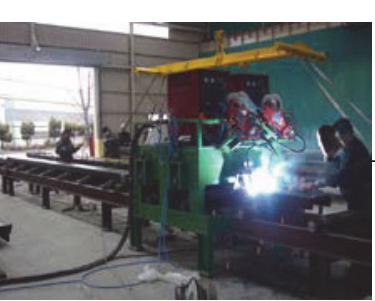

Welding

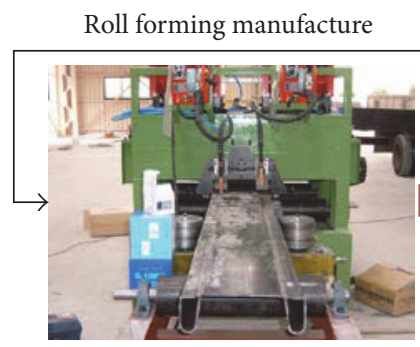

Welding

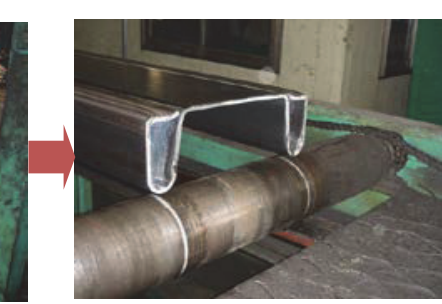

Cutting

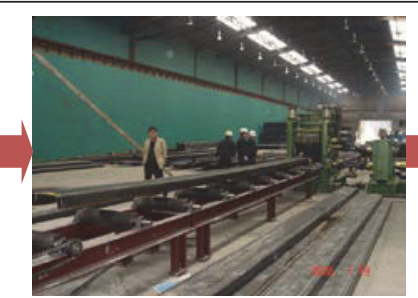

Correction

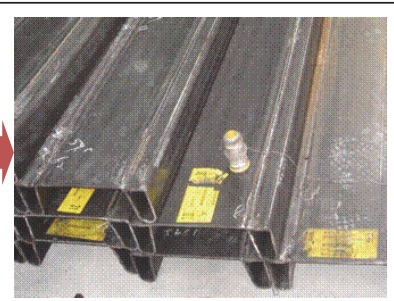

Ready for sale

FIGURE 10: Pilot production process for the developed MCO beam. 


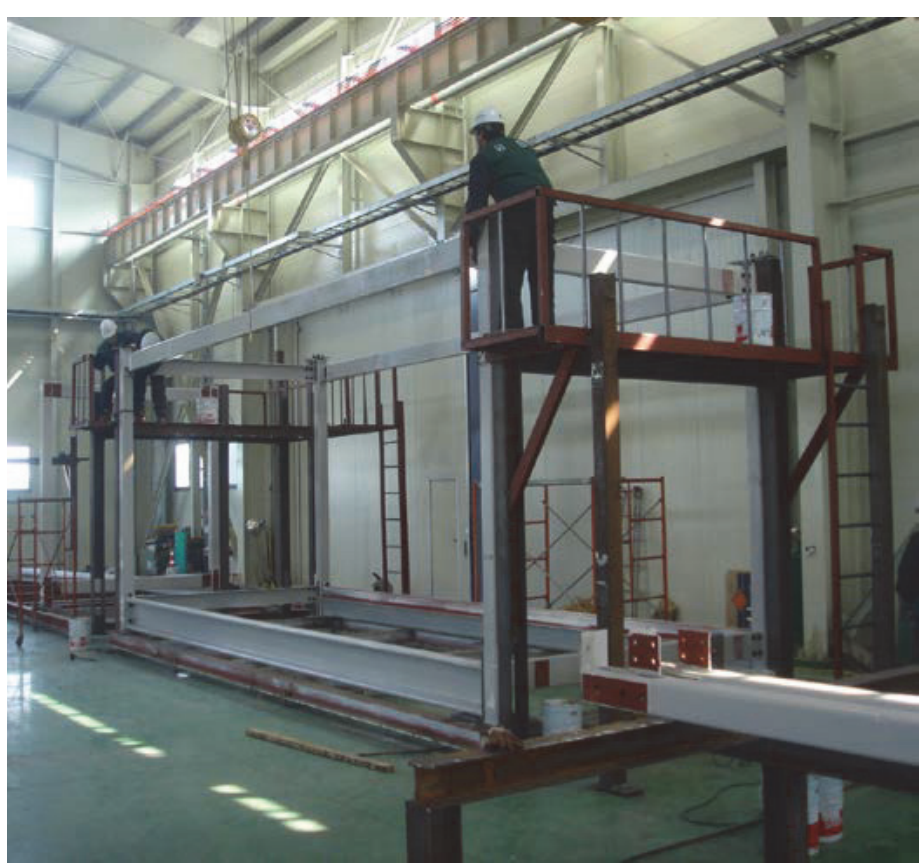

Assembled modular unit

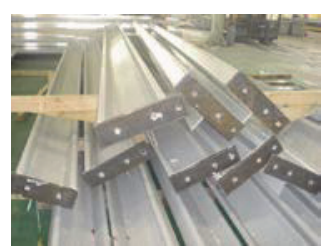

Welding end plates

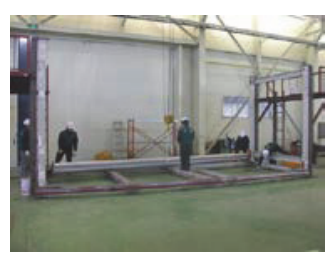

Assemble module with MCO beams

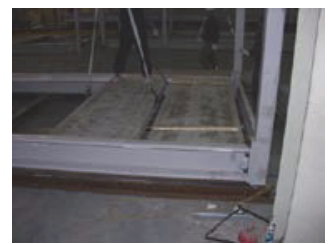

Install PC slabs on floor beams

FIgURE 11: Assembled modular unit with the produced MCO beams.

TABLE 12: Design targets and test results for the produced MCO beams.

\begin{tabular}{lcc}
\hline Design factors & Design targets & Test results \\
\hline Verification of CTQ & Less than 2 & 2 \\
$\quad$ Welding length per unit length $(\mathrm{m} / \mathrm{m})$ & Larger than 150 & Average 183.86 \\
$\quad$ Moment of inertia per unit sectional area of beam $\left(\mathrm{cm}^{2}\right)$ & Less than 0.25 & 0.18 \\
Weight of floor beams per unit area $\left(\mathrm{kN} / \mathrm{m}^{2}\right)$ & Less than 0.28 & 0.25 \\
$\quad 6 \mathrm{~m}$ span & Less than 0.35 & 0.32 \\
$7.5 \mathrm{~m}$ span & & Less than $0.05 \%$ \\
$8.1 \mathrm{~m}$ span & Flexural deformation is less & Less than $3 \mathrm{~mm}$ \\
Pilot test & than $0.05 \%$ & Tolerance of $3 \mathrm{~mm}$
\end{tabular}

can be utilized to develop other types of structural modular beams and can satisfy the diverse requirements of different customer groups.

\section{Competing Interests}

The authors declare that there is no conflict of interests regarding the publication of this article.

\section{Acknowledgments}

This research was supported by a grant from the National Research Foundation of Korea (Grant no. NRF-2016 R1D1A1B01010615).

\section{References}

[1] R. M. Lawson, R. G. Ogden, and R. Bergin, "Application of modular construction in high-rise buildings," Journal of Architectural Engineering, vol. 18, no. 2, pp. 148-154, 2012.

[2] S.-G. Hong, B.-H. Cho, K.-S. Chung, and J.-H. Moon, "Behavior of framed modular building system with double skin steel panels," Journal of Constructional Steel Research, vol. 67, no. 6, pp. 936-946, 2011.

[3] H.-J. Kim, J.-S. Lee, H.-Y. Kim, B.-H. Cho, Y. Xi, and K.-H. Kwon, "An experimental study on Fire resistance of medical modular block," Steel and Composite Structures, vol. 15, no. 1, pp. 103-130, 2013.

[4] T.-S. Eom, T.-H. Ha, B.-H. Cho, and T.-H. Kim, "Cyclic loading tests on framed stud walls with strap braces and steel sheathing," 
Journal of Structural Engineering, vol. 141, no. 7, Article ID 04014173, 2015.

[5] L. S. Pheng and M. S. Hui, "Implementing and applying six sigma in construction," Journal of Construction Engineering and Management, vol. 130, no. 4, pp. 482-489, 2004.

[6] J. A. Johnson, H. Gitlow, S. Widener, and E. Popovich, "Designing new housing at the University of Miami: a 'six sigma' (C) DMADV/DFSS case study," Quality Engineering, vol. 18, no. 3, pp. 299-323, 2006.

[7] Y. Akao, "Development history of quality function deployment," The Customer Driven Approach to Quality Planning and Deployment, 1994.

[8] A. Hassan, A. Siadat, J.-Y. Dantan, and P. Martin, "Conceptual process planning an improvement approach using QFD, FMEA, and $\mathrm{ABC}$ methods," Robotics and Computer-Integrated Manufacturing, vol. 26, no. 4, pp. 392-401, 2010.

[9] J. Chun and J. Cho, "QFD model based on a suitability assessment for the reduction of design changes in unsatisfactory quality," Journal of Asian Architecture and Building Engineering, vol. 14, no. 1, pp. 113-120, 2015. 

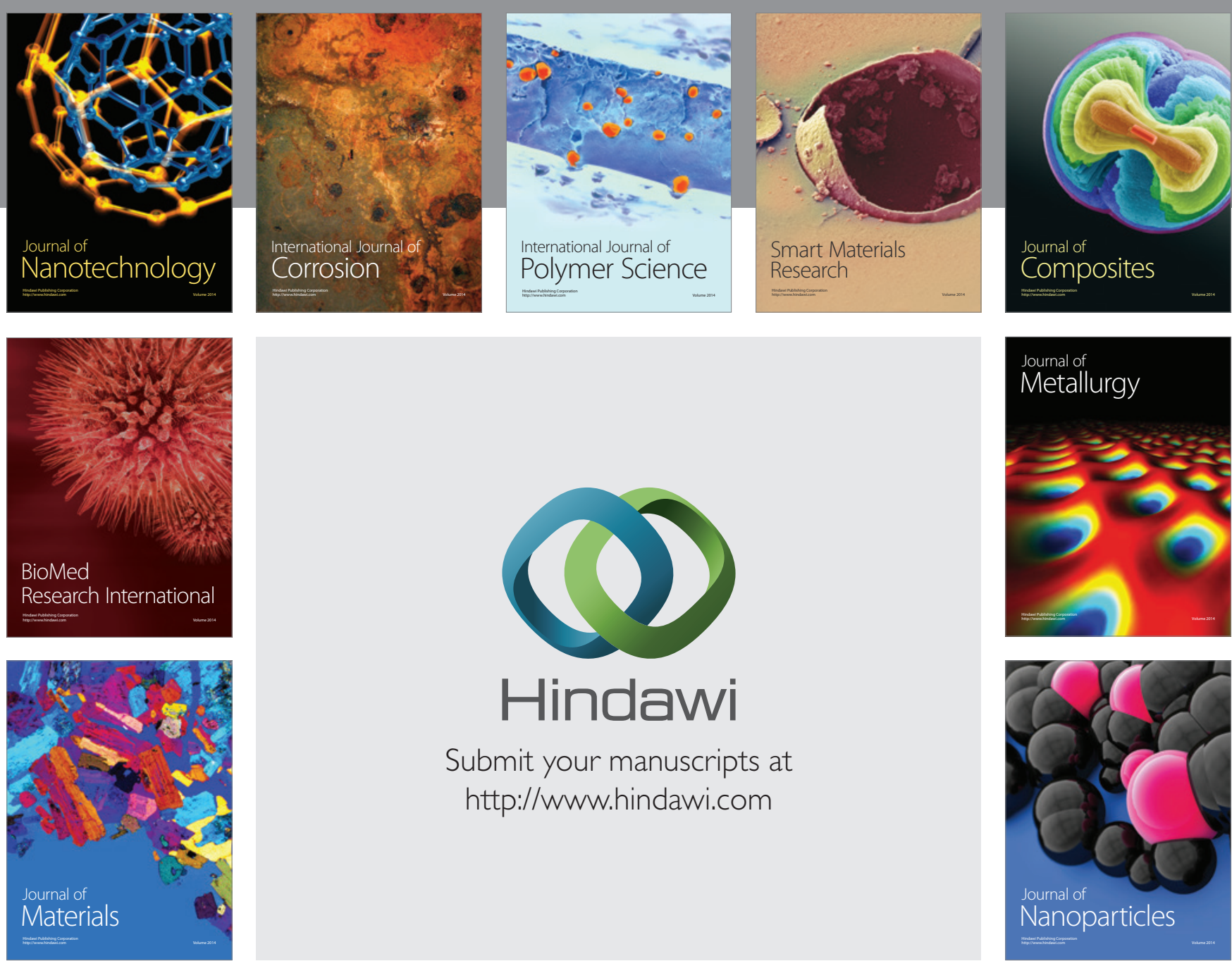

\section{Hindawi}

Submit your manuscripts at

http://www.hindawi.com

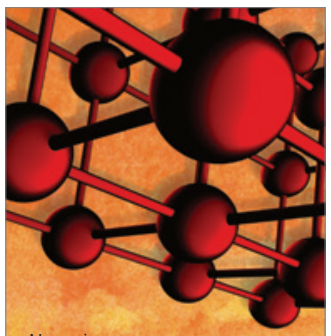

Materials Science and Engineering
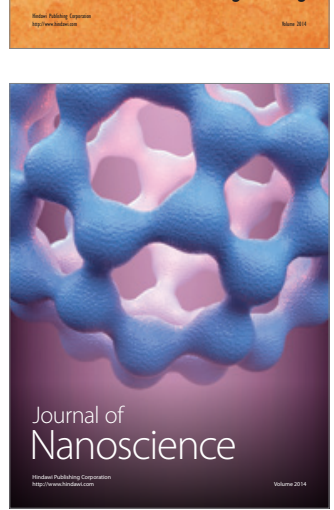
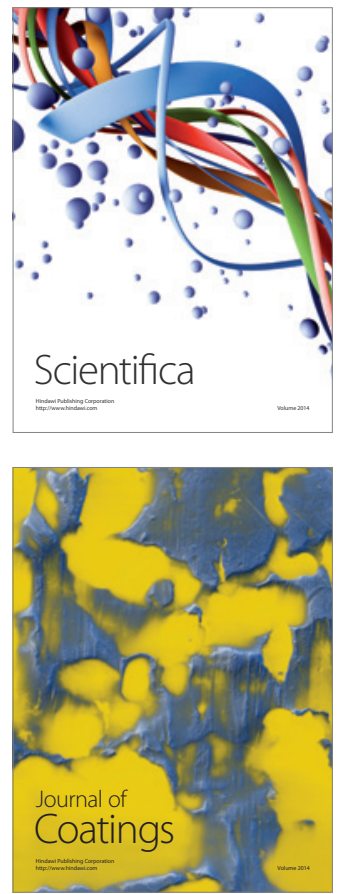
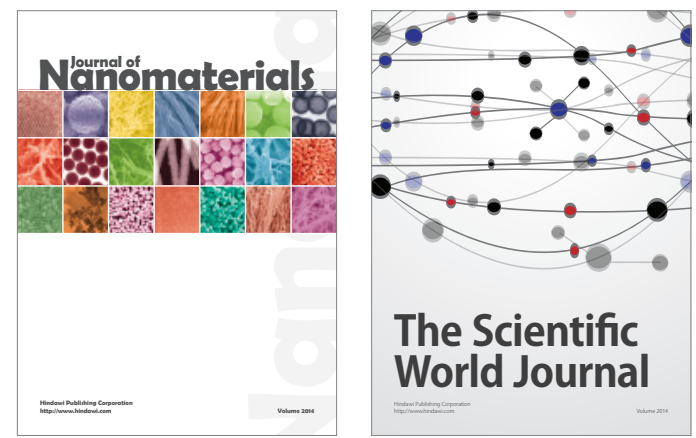

The Scientific World Journal
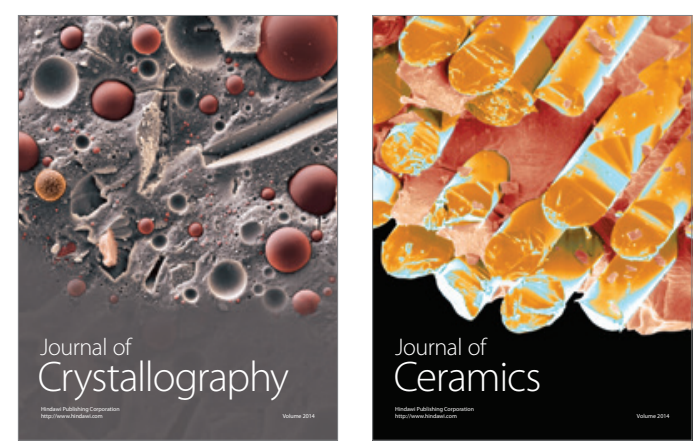
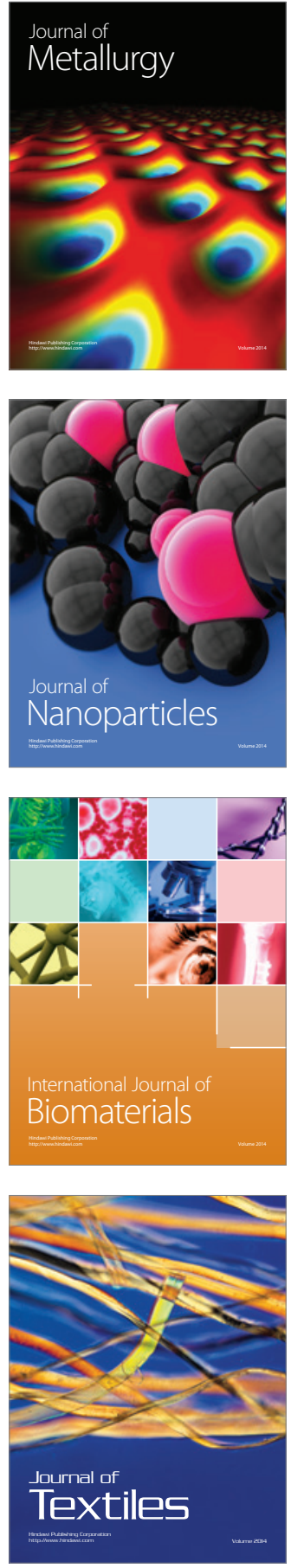